\title{
Systemic Deficiency of the First Component of the Pyruvate Dehydrogenase Complex
}

\author{
DOUGLAS S. KERR, LAP HO, CHESTON M. BERLIN, KATHRYN F. LANOUE, \\ JAVAD TOWFIGHI, CHARLES L. HOPPEL, MARILYN M. LUSK, CAROL M. GONDEK, AND \\ MULCHAND S. PATEL
}

Departments of Pediatrics, Biochemistry, and Medicine, Rainbow Babies and Childrens Hospital, and Veterans Administration Medical Center, Case Western Reserve University School of Medicine, Cleveland, OH 44118; and Departments of Pediatrics, Biochemistry, and Pathology, Hershey Medical Center, Pennsylvania State University, Hershey, PA 17033

\begin{abstract}
An infant with lactic acidosis and developmental delay had neuropathological changes consistent with Leigh's necrotizing encephalomyelopathy. Total pyruvate dehydrogenase complex (PDC) activity was low relative to controls in lymphocytes $(0.2$ versus $1.9 \pm 0.6$ $\mathrm{SD} \mathrm{nmol} / \mathrm{min} / \mathrm{mg}$ protein) and cultured skin fibroblasts $(0.9$ versus $2.7 \pm 1.0$ ). Liver, muscle, heart, and kidney mitochondria oxidized several substrates normally, but did not oxidize pyruvate. PDC activity was absent in these mitochondria (0.1 versus $9.8 \pm 4.2$ in liver and 0.7 versus $75 \pm 26$ in muscle) and was very low in all tissue homogenates. Activity of the first component was low in liver mitochondria, whereas activities of the second and third components were normal. Western blot analysis of tissue proteins showed normal amounts of second and third component of PDC but undetectable to trace amounts of both $\alpha$ and $\beta$ subunits of the first component of PDC in liver, brain, kidney, heart, and skin fibroblasts. Thus, profound systemic deficiency of PDC was due to lack of both subunit proteins of the first component of PDC. (Pediatr Res 22: $312-318,1987$ )
\end{abstract}

\section{Abbreviations}

PDC, pyruvate dehydrogenase complex

$E_{1}$, first component of PDC (pyruvate dehydrogenase)

$E_{2}$, second component of PDC (dihydrolipoyl transacetylase)

$\mathrm{E}_{3}$, third component of PDC (dihydrolipoamide dehydrogenase)

MOPS, morpholinopropane sulfonic acid

SDS, sodium dodecyl sulfate

PDC catalyses a key regulatory step in energy metabolism, the irreversible oxidation of pyruvate to acetyl-CoA, which permits energy derived from carbohydrate to enter the Krebs cycle. Defects of PDC have been described in association with a variety

Received January 20, 1987: accepted April 14, 1987

Correspondence and reprint requests Douglas S. Kerr, M.D. Department of Pediatrics. Rainbow Babies and Childrens Hospital, 2074 Abington Road, Cleveland. OH 44106

Supported by the National Institute of Arthritis, Diabetes, Digestive and Kidney Diseases, Grant AM 20478. L.H. is a predoctoral fellow supported by N.I.H. Metabolism Training Grant AM 07319.

'Subsequent to investigation of the present case, we have assayed cells and tissues from two brothers who have normal PIC activity in skin fibroblasts but lack PDC activity in lymphocytes. PDC activity was present in kidney, but not in liver, muscle, and heart (41). of clinical syndromes. Common features of these disorders include lactic acidosis and neurological dysfunction, but there is great variation of the severity and systemic expression of reported defects. This heterogeneity may not seem surprising, considering the many possibilities for genetic variation affecting this multienzyme complex containing at least six gene products which, if defective, could result in loss of activity. To date, some 90 individuals with defects of PDC have been described $(1,2)$, but relatively few of these cases have been investigated in detail.

Approximately 28 cases of defects involving $E_{1}$ have been reported $(1-11)$. Most of these defects have been characterized by decreased activity of PDC in skin fibroblasts and by decreased activity of the $E_{1}$ component assayed by a partial reaction in which ferricyanide was used as an artificial electron acceptor (3, 12). The activities of PDC and $E_{1}$ were measured in white blood cells in one case and in homogenates of other tissues in two patients $(3,4,7)$. Immunological techniques have been applied to the analysis of PDC mutants (9-11), and decreased enzyme activity has been described in association with a decrease of immunoreactive protein in two cases of $E_{1}$ deficiency $(10,11)$ and in one case which involved the $\mathrm{E}_{3}$ component (13).

We have investigated a case of severe PDC deficiency in some detail utilizing the combined resources of several laboratories to determine the systemic physiological consequences and mechanisms responsible for profound deficiency of this key enzyme of energy metabolism.

\section{METHODS}

Human subjects. Collections of blood and tissue specimens from the patient and controls were carried out with informed consent according to protocols approved by the Institutional Review Board of University Hospitals of Cleveland. Blood samples for preparation of lymphocyte controls were obtained from adult volunteers. Skin fibroblast controls were obtained from established cell lines derived from infants and children and forwarded to us from a number of laboratories along with cells sent for analysis of possible defects of pyruvate metabolism. Samples of liver and rectus abdominus muscle used for control data were obtained from 12 children who underwent elective biopsies for diagnosis of a variety of other defects associated with lactic acidosis or abnormalities of fatty acid oxidation. Rectus abdominus muscle biopsies for preparation of mitochondria were also obtained from six adults undergoing elective abdominal surgery.

Preparation of lymphocytes and fibroblasts. Lymphocytes were obtained from whole blood collected under sterile conditions, anticoagulated with citrate-phosphate-dextrose-adenine solution (CPDA-1, $0.15 \mathrm{ml} / \mathrm{ml}$ blood; Fenwal Laboratories, Deerfield, 
II.). shipped as whote blood along with control blood samples from two adult volunteers, and separated for assay after two days. I.ymphocytes were isolated by the Ficoll-Paque method (Pharmacia Inc.. Piscataway. NJ) (14), and the final pellet was resuspended in phosphate-buffered saline. Skin fibroblasts were cultured in $1: 12$ medium (Cibco laboratories. (hagrin Ialls. OH) with $16 \%$ fetal calf serum. fortified with penicillin and streptomycin, and subcultured until sufficient cells reached confluence ( 3 T75 flasks required to provide sufficient protein for assay of $P D()$. The cells were harvested with $0.5 \%$ trypsin. seraped off with a rubber policeman. and washed in phosphatebuffered saline prior to preparation for assay.

Enzlme assals. PI) ('activity was measured as thiamine pyrophosphate and coenzyme $\wedge$-dependent decarboxylation of $[1$ ${ }^{14} \mathrm{C}$ ]pyruvate by the method of Sheu ${ }^{\prime}$ al. (15), with the following minor modifications. (ells or mitochondria were preincuhated for $15 \mathrm{~min}$ in the presence of either dichloroacetate. $5 \mathrm{mM}$. or fluoride, $50 \mathrm{mM}$. frosen and thawed twice, and incubated in 0.1 $\mathrm{ml}$ final volume of the assay mixture as previously described (15). with the addition of fetal calf serum, $2.5 \%$. The incubation tube was sealed with a serum stopper from which a plastic cup was suspended. containing filter paper impregnated with hyamine hydroxide. Incubation times varied from 4 to 20 min for fibroblasts, lymphocvtes, and mitochondria. After trapping the evolved ${ }^{1.1} \mathrm{C}^{\prime} \mathrm{O}$. the entire cup and hyamine saturated filter paper was transferred to a vial for liquid scintillation counting. Thiamine pyrophosphate and coenzyme $\wedge$ were omitted from blank tubes. Fach assay included quadruplicate reaction tubes and quadruplicate blanks for each of the following conditions: untreated, dichloroacetate activated, and fluoride inactivated cells or mitochondria. (ontrol cells or mitochondria were prepared simultaneously with samples from the patient and included in each assay.

$\mathrm{F}_{1}$ was assayed in the same way except that coenzyme $A$ and NAI) were omitted and ferricyanide. $67 \mathrm{mM}$. was added. It was found that ferricyanide is not required for this reaction with crude homogenates or even with purified PI) (, but the reaction is dependent on added thiamine pyrophosphate. which was omitted from the blank. Although phosphorylation-regulated activity of $\mathrm{I}$, is considered rate limiting for $P D C$. the rate of this nonphysiological partial $Z_{1}$ reaction is less than $10 \%$ of the rate of the overall $P I X C^{\prime}$ reaction, since continuing transfer of the acetyl group from thiamine pyrophosphate to the lipoyl moiety of $\mathrm{F}$ is not possible in the absence of eonzyme $A$ and $V \wedge I) F_{2}$ was assayed by acetylation of reduced lipoamide with $\left[1-{ }^{1.4} \mathrm{C}\right]$ acetyl-Co^ (14). To correct for a significant nonen symatic rate for this reaction. extracts were omitted from blanks which were incubated for the same time. $I_{3}$ was assayed spectrophotometrically by reduction of $\mathrm{N} A D$ in the presence of reduced lipoamide and/or by oxidation of $\mathrm{NADH}$ in the presence of lipoamide (16). Pyruvate carboxylase and phosphoenolpyruvate carboxykinase were measured by fixation of ${ }^{14} \mathrm{CO}$, and conversion of the oxalacetate formed to citrate or malate, as previously described (15). Protein was measured by the method of lowry using bovine serum albumin as a standard (18).

Preparation of initochondria. Samples of liver, skeletal muscle. heart. and kidney obtained within an hour of death were placed in ice cold media $(\wedge)$ containing: mannitol, $225 \mathrm{mM}$; sucrose. $75 \mathrm{mM}$; MOPS, $5 \mathrm{mM}$, pH 7.0); and FITA, $50 \mu \mathrm{M}$. All tissues were mineed and rinsed free of blood in media $\wedge$. I.iver and kidney tissues were homogenized in $50 \mathrm{ml}$ per $\mathrm{g}$ wet weight of media $A$ by brief treatment (10) s) with a Polytron tissue disrupter set at low speed, and the mitochondria were isolated by standard techniques of differential centrifugation (19). The cardiac and skeletal muscle minced specimens were transferred to a different media (B), $10 \mathrm{ml} / \mathrm{g}$ wet weight, which contained: $\mathrm{KCl}, 140 \mathrm{mM}$ : $\mathrm{Mg}\left(\mathrm{l}_{2}, 2.5 \mathrm{mM}: \triangle\right.$ TP, $2.5 \mathrm{mM}$; FDT, 5()$\mu \mathrm{M}$ : MOPS, $5 \mathrm{mM}$, pH 7.0; and Nagarse protease, $(0.4 \mathrm{mg} / \mathrm{ml}$. The minces were kept on ice with the protease for $5 \mathrm{~min}$ and then diluted 10 -fold with media $\mathrm{B}$ and homogenized with a polytron tissue disrupter at low speed for 10 s. The homogenates were centrifuged at 2.00() $\times g$ for 5 min and the pellets discarded. The supernatants were centrifuged at $80(0) \times g$ for $10 \mathrm{~min}$ and the pellets saved. The pellets were resuspended and washed twiee in medial A. I iver mitochondria from control subjects were prepared in a similat manner. as previously described (2)). Skeletal muscle mitochondria from control subjects were prepared with minor variations from the method above, as previously described (21) with addition of ATP. $1 \mathrm{mM}$. and $\mathrm{MgC} 1,5 \mathrm{mM}$ (22. 23).

Orrgen uptake studies. Oxidation of substrates by freshly isolated mitochondria from the patient was measured polarographically with a (lark electrode at $28^{\circ}$. The incubation buffer contained $\mathrm{K}(\mathrm{l} .150 \mathrm{mM}$ : MOPS. $20 \mathrm{mM}$ : KH,P(). $5 \mathrm{mMl}$ : and FIDIA. $50 \mu \mathrm{M}$ : at pH 7.2. Fndogenous substrates were depleted by addition of ADP. followed by addition of specific substrates at the concentrations shown in Table 2. Rates of oxygen uptake were determined in the presence and absence of ADP. $5 \mathrm{mM}$ (corresponding to states 3 and 4 respectively). and the respiratory control ratio (state $3 /$ state 4 ) determined (24). D) ata from control liver and skeletal muscle mitochondria were obtained at $30^{\circ}$ by similar techniques (see Table 2) (2.3).

Immonoasars. PI) components were analyed by the Western blot method (!(0). Frozen tissues or mitochondria were suspended in potassium phosphate. $20 \mathrm{mM}$. pH 7.0). and Triton $\mathrm{X}-100.1 \mathrm{f}$. The samples were sonicated for two 10 -s continuous pulses with a microtip. followed by centrifugation $(12.00(0) \times$ $15 \mathrm{~min}, 4^{\circ}$ ). Aliquots of the supernatant were dissociated by boiling for $10 \mathrm{~min}$ in dithiothreitol. $17 \mathrm{mM}$. and $\mathrm{SH} S \mathrm{~S}$. $2 \%$. Protein extracts were separated by electrophoresis in discontinuous SDS-polyacrylamide gels $(6 \%$ polyacrylamide stacking: $9 \%$ polyacrylamide separation) (25). Proteins were electrocluted from the gel onto a nylon-based membrane (Zeta-probe. Biorad laboratories. Richmond. (A) with a Bio-Rad transhlot apparatus at room temperature for $8 \mathrm{~h}$ at 75 mamp. essentially als described in Bio-Rad instruction manual no. 85-(0) 76-485. The membranes were then incubated with specific antisera followed

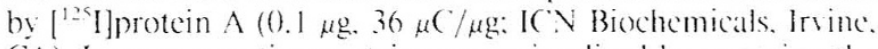
(A). Immunoreactive proteins were visualized by exposing the membrane to X-(Omat AR film (Fastman Kodak (o.. Rochester. NY). Where indicated. a goal antirabbit $\lg ($ i conjugated with horseradish peroxidase was used instead of $\left[{ }^{2}=1\right]$ protein $A$ and immunoreactive proteins vistalized by stain deposition from the oxidation of 4-chloro-1-napthol, following the procedure described in Bio-Rad instruction manual no. 83-0)(0)7-0283.

Antisera against individual components $I_{1}, B_{2}$ and $I_{\text {; }}$ were raised in rabbits using purified enzymes and standard immunization procedures (26.27). Antigens for immuniation of rabbits were obtained as follows: purified bovine kidney $\mathrm{I}$, was a gift from Dr. Tracy I inn to the late Merton Wter, bovine heart l: was a gift from Dr. Lester Reed, and porcine heart 1 ; was obtained from a commercial source (Sigma (hemical (o.. St. I.ouis, MO). Bovine $F_{1}$ and $F_{\text {s }}$ used as standards were also generously provided by Dr. L.. Reed. The anti-L, and anti-l: sera are specific for the $F_{1}$ and $F_{2}$ components of $\left.P I\right)($. respectively. In contrast, the anti-E; serum reacts with the $1:$; components of pyruvate, $\alpha$-ketoglutarate, and branched-chain a-hetoacid dehydrogenase complexes (Carothers D), Patel MS. unpublished data). For immunoblot analysis. antisera were diluted with TrisCl. $20 \mathrm{mM}$. pH 7.5: $\mathrm{NaCl} .500 \mathrm{mM}$ : and bovine serum albumin. $5 \%$. Antisera for $E_{1} E_{2}$. and $E_{3}$ were diluted 20-. 50 and 50-fold. respectively. Deoxyribonucleic acid was assayed fluorometrically using salmon sperm DNA as a standard (28).

\section{( $A S F:$ RIPORT}

The patient was the product of a 37-wh pregnancy in a 19-yrold primiparous mother. The pregnancy was complicated by preeclampsia treated with hydralazine and $\mathrm{MgSO}$. The infant was small for gestational age with a birth weight of $2325 \mathrm{~g}$. Apgar scores were $6(1 \mathrm{~min})$ and $9(5 \mathrm{~min})$. Shortly after birth the baby 
was noted to be flaccid and required oxygen for a brief period. Blood gases revealed metabolic acidosis ( $\mathrm{pH} 7.29$; bicarbonate, $8 \mathrm{mEq} /$ liter). The patient was transferred to Hershey Medical Center. The acidosis was corrected with sodium bicarbonate. The patient initially was moderately hypotonic but gradually improved. Responsiveness to auditory stimuli was diminished and an intermittent strabismus was present. An ultrasound examination of the brain was normal. There was no evidence of cardiac disease. Blood ammonia was 71 and $45 \mu \mathrm{M}$ when repeated. Metabolic screening tests showed increased alanine in serum and urine. Organic acid analysis of the urine by gas chromatography showed greatly increased lactic acid $(3065 \mathrm{mg} / \mathrm{mg}$ creatinine). Blood lactate was $5.8 \mathrm{mM}$ (normal 0.5-2.2).

Following the first hospitalization the patient was given a standard infant formula with addition of sodium bicarbonate, 2 $\mathrm{mEq} / 4 \mathrm{oz}$ feeding, later increased to $5 \mathrm{mEq}$. He gained weight slowly (25th percentile). At age 3 months he was hospitalized following a brief tonic clonic seizure and an apneic episode. On admission he was noted to have poor head control, a weak cry, and intermittent strabismus. Blood lactate was $8.0 \mathrm{mM}$. Treatment with phenobarbital was started, but in the hospital he continued to have brief seizures until phenytoin was added. There were no further seizures for the duration of his life. On two occasions his EEG was normal. His opthalmological examination was normal, with no evidence for optic atrophy. An NMR imaging scan of the head was interpreted as possibly showing increased density lateral to the midportion and posterior to both lateral ventricles, perhaps due to a demyelinating process. His cardiovascular examination and an electrocardiogram were normal. Plasma total carnitine was $25 \mathrm{nmol} / \mathrm{ml}$ (low normal). A chromosome analysis was normal. Prior to discharge the dose of bicarbonate was increased to $7 \mathrm{mEq}$ per feed. He was treated briefly with biotin, $10 \mathrm{mg} /$ day, without apparent benefit.

When a metabolic diagnosis was made, the formula was modified by addition of vegetable oil to provide $60 \%$ of energy as fat, $110 \mathrm{kcal} / \mathrm{kg} /$ day, and approximately $2.0 \mathrm{~g}$ protein $/ \mathrm{kg} /$ day. The bicarbonate dose was gradually increased to $15 \mathrm{mEq}$ every $4 \mathrm{~h}$. However, during the second 6 months of life, the patient gained weight slowly, had increased lethargy, poor feeding, and occasional fevers of undetermined etiology. Feeding became progressively more difficult, eventually requiring that he be fed by nasogastric tube. At age 9 months blood lactate was $11 \mathrm{mM}$ and pyruvate was $0.95 \mathrm{mM}$, giving a ratio of 12 (normal 10-20). After 10 months age, he had five more hospital admissions for bronchiolitis, apnea, or metabolic acidosis. The final hospitalization at age 12 months was for marked lethargy and fever. In the hospital, 2 days before death, he had a respiratory arrest with severe metabolic acidosis ( $\mathrm{pH} 7.03$ ). He was rapidly resuscitated but required large amounts of sodium bicarbonate and remained ventilator dependent and hypotensive. He developed fixed dilated pupils, an EEG showed flat brain wave function, and he was pronounced dead. Permission was given for an immediate autopsy.

Autopsy showed bronchopneumonia, septicemia, and acute focal septic hepatitis. There was no evidence of cardiac or skeletal muscle abnormalities by gross examination, or light or electron microscopy. The remaining abnormalities were confined to the central nervous system. There was symmetrical focal cystic necrosis of much of the putamen and less severely of the caudate nuclei, characterized by neuronal loss and astrocytosis without remarkable vascular proliferation. There was mild hypomyelination of the white matter of the cerebral hemispheres and loss of myelinated axons from the central portions of the optic nerves and posterior columns of the spinal cord. The latter also showed vacuolation. The hypothalamus, mammilary bodies, midbrain, and pons appeared normal. In addition, there were changes consistent with diffuse acute anoxic-ischemic damage involving cerebral and cerebellar cortices, basal ganglia, thalami, and reticular nuclei of the medulla. These changes included eosinophilia of neurons and varying degrees of vacuolization of neuropile.
There was also evidence of recent necrosis of the posterior horns and chromatolysis of the anterior horns in the lumbo-sacral spinal cord. The spinal roots showed a moderate degree of axonal degeneration.

\section{RESULTS}

$P D C$ activity in fibroblasts and lymphocytes. Deficiency of PDC activity was initially detected in lymphocytes isolated from whole blood. Lymphocyte PDC activity is normally similar to that in fibroblasts, and can be activated by preincubation with dichloroacetate or inactivated by preincubation with fluoride (Table 1) (29). Dichloroacetate-treated lymphocytes from the patient had less than $10 \%$ as much activity as a concurrent control or than the average activity found in other controls; untreated lymphocytes had $6 \%$ as much activity as controls. The activity in cultured skin fibroblasts, assayed on two separate occasions, was somewhat higher, corresponding to about a third of the average activity found in dichloroacetate-activated or untreated control fibroblasts. The range of activity found in control lymphocytes and fibroblasts is quite large, but the activity in both types of cells from the patient was less than the lower range of controls.

Lymphocytes from the patient's mother were obtained for measurement of PDC activity (the father was not available). The activity after dichloroacetate treatment was $1.4 \mathrm{nmol} / \mathrm{min} / \mathrm{mg}$ protein, which is within $1 \mathrm{SD}$ of the mean of controls.

Oxidation of substrates by intact mitochondria. Within $1 \mathrm{~h}$ of the patient's death, samples of liver, skeletal muscle, heart, and kidney were obtained for preparation of mitochondria. Mitochondria prepared from rat liver served as a concurrent control. The freshly isolated mitochondria were incubated with a number of substrates and oxygen uptake was measured in the presence and absence of ADP. The mitochondria oxidized most of the substrates tested very actively and showed appropriately high respiratory control ratios, in the range of 4 to 10 with glutamate. Therefore, these were relatively intact mitochondria despite having been obtained postmortem. The ADP stimulated rates of oxidation of palmitoyl-carnitine and succinate are equal to those we found with human liver and skeletal muscle mitochondria prepared from biopsies obtained from control child and adult subjects (Table 2). The rates of oxidation of substrates other than pyruvate by the patient's heart and kidney mitochondria appear normal compared to rates previously reported for heart and kidney mitochondria from rats or rabbits $(30,31)$ and a human subject (32).

Addition of pyruvate did not result in any measurable increase in the rate of oxygen uptake by any of these four types of mitochondria. They appeared to be completely unable to oxidize pyruvate. Oxidation of pyruvate by intact mitochondria normally requires catalytic amounts of malate as a source of oxalacetate in order to remove acetyl-CoA, the product of pyruvate oxidation, by formation of citrate. In the presence of malate alone, there was a slow basal rate of oxidation, at least by liver,

Table 1. Pyruvate dehydrogenase complex activity in lymphocytes and fibroblasts (nmol/min/mg protein)

\begin{tabular}{ccccc}
\hline \multirow{2}{c}{ Cell type } & Subject & Untreated & $\begin{array}{c}\text { Dichloroacetate } \\
\text { activated }\end{array}$ & $\begin{array}{c}\text { Fluoride } \\
\text { inactivated }\end{array}$ \\
\hline Lymphocytes & Patient & 0.05 & 0.16 & 0.02 \\
& $\begin{array}{l}\text { Controls* } \\
\text { (Range) }\end{array}$ & $0.83 \pm 0.39$ & $1.89 \pm 0.65$ & $0.51 \pm 0.38$ \\
& $(0.25-1.92)$ & $(0.92-3.33)$ & $(0.13-1.84)$ \\
Fibroblasts & & & & \\
& Patient & $0.52,0.34$ & $0.83,0.88$ & $0.18,0.07$ \\
& $\begin{array}{l}\text { Controls } \dagger \\
\text { (Range) }\end{array}$ & $1.70 \pm 0.84$ & $2.69 \pm 0.98$ & $1.21 \pm 0.72$ \\
& $(0.47-3.92)$ & $(1.13-6.67)$ & $(0.07-3.30)$ \\
\hline
\end{tabular}

${ }^{*}$ Control values for lymphocytes from 45 normal adults, mean $\pm \mathrm{SD}$. SD. 
heart, and kidney mitochondria. When pyruvate and ADP were added, there was no increase in oxygen uptake with any of the patient's mitochondria, in contrast to the large increase observed with liver and muscle mitochondria from controls or that reported for kidney and heart mitochondria from animal and human sources $(3()-32)$.

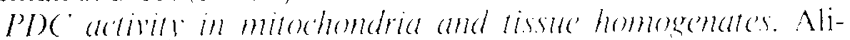
quots of fresh intact mitochondria from the patient and controls were preincubated with either dichloroacetate or fluoride before assay of $P I)($. There was virtually no detectable $P D($ activity in any of the patient's mitochondria whether untreated. activated with dichloroacetate, or inactivated with fluoride (Table 3). The activity in liver and muscte mitochondria was less than $2 \%$ of the average of controls. The activity in kidney or heart mitochondria was much less than a single control: the relative activity of PI)( in rat kidney or heart is higher than in liver or skeletal muscle. respectively (33).

PDC activity was also measured in frozen whole tissues obtained from the patient at autopsy and from controls. The

\begin{tabular}{|c|c|c|c|c|c|}
\hline Substrates & Subject & livert & Musclet: & Heartş̧ & Kidneys \\
\hline Malate & $\begin{array}{l}\text { Patient } \\
\text { Controls }\end{array}$ & $\begin{array}{c}8 \\
13 \pm 3\end{array}$ & $\begin{array}{c}0 \\
8 \pm 7\end{array}$ & 35 & 2.3 \\
\hline Pyruvate + malate & $\begin{array}{l}\text { Paticnt } \\
\text { Controls }\end{array}$ & $\begin{array}{c}8 \\
21 \pm 4\end{array}$ & $\begin{array}{c}0 \\
107 \pm 27\end{array}$ & .34 & 24 \\
\hline $\begin{array}{l}\text { Cilutamate }+ \\
\text { malate }\end{array}$ & $\begin{array}{l}\text { Pationt } \\
\text { Controls }\end{array}$ & $\begin{array}{c}44 \\
32 \pm 6\end{array}$ & $11.3 \pm 14$ & 311 & 76 \\
\hline $\begin{array}{l}\text { Palmitoyl-carnitine } \\
\quad+\text { malate }\end{array}$ & $\begin{array}{l}\text { Pationt } \\
\text { Controls }\end{array}$ & $\begin{array}{l}27 \\
3() \pm 8\end{array}$ & $7.3 \pm 6$ & 276 & 58 \\
\hline $\begin{array}{l}\text { Succinate + rote- } \\
\text { none }\end{array}$ & $\begin{array}{l}\text { Patient } \\
\text { Controls }\end{array}$ & $\begin{array}{c}66 \\
50+27\end{array}$ & $\begin{array}{c}65 \\
145 \pm 18\end{array}$ & 145 & 88 \\
\hline
\end{tabular}

* State 3 rates (in the presence of $A \mathrm{I}) \mathrm{P}$. $5 \mathrm{mM}$ ), natoms $(0 / \mathrm{min} / \mathrm{mg}$ protein. Substrate concentrations used with the patient's mitechondria were as follows: malate $1 \mathrm{mM}$ : pyruvate, $5 \mathrm{mM}$ : glutamate. $10 \mathrm{mM}$ for liver and kidney and $20 \mathrm{mM}$ for heant and skeletal muscle: palmitoylcarnitine, $50 \mu \mathrm{M}$ : succinate. $10 \mathrm{mM}$ : and rotenone, $5 \mu \mathrm{M}$. Substrate concentrations used for controls were similar. except for malate. $5 \mathrm{~m}$ : and pyruvate, $10 \mathrm{mM}$ : glutamate was assayed in the livers from controls without added malate.

+ liver controls from live infants with other disorders. mean \pm SD).

I Muscle controls from five children and adults. mean \pm S1) (23).

s. See text for references for control dala for kidney and heart. activities of PIX in the patient's brain and kidney were about ! to $4 \%$ of the average of eontrols and the activities in heart and liver were about 6 to $12 \%$ of controls respectively. Therefore. PDC activity was extremely low in all tissues tested from this patient as well as in isolated mitochondria. Since PI) $($ is a mitochondrial ensyme. the apparent difference between the patient and controls was not as striking in comparing the frocen tissues.

ferivity of the complenemes of Pl) . Activities of the three catalutic components of the PIC were assared in skin fibroblasts and in liver and muscle mitochondria (lable t). Activity of $b_{1}$. which is a partial reaction. is normally wery show being only about $5 \%$ of the overall reaction rate. The activity of $k_{1}$ in livet mitochondria from the patient was barely detectable, about $10{ }^{\prime}$; of the average of controls. It has been generally assumed that ferricvanide acts as an artificial electron aceeptor in this reaction. but we found that ferricyanide is not recpuired. The rate of $t_{2}$ in tibroblasts was relatively higher. about half that of eontrols. ()n the other hand the activities of $\mathrm{E}$ and $\mathrm{E}$; in fibroblasts and liver and muscle mitochondria were nomal refative to controls the activity of 1 : was lower in muscle mitochondria from the patient than controls, but it is suspected that this was an artifact due to a technical problem in preparation of these mitochondria resulting in a low vield). In addition. the activities of two othere ensmes of pyruate metabolism. pyruvate catboxylase. and phosphosenolprovate carboxvinase were normal in lymphocytes hibroblasts, and liver mitechondrial (Table 5 ).

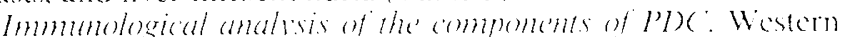
blot analysis was used to compare extracts of liver mitochondria and whole liver (Fig. 1). kidney, heart, and brain (lig. 2) from the patient and from the control infant subject with normal $P I)($ activity described above. Fqual quantities of protein from the patient and control showed similar amounts of an immunorcactive protein corresponding to purified bovine heart $1:$ and $\mathrm{l}$; (Figs. 1 and 2). Bovine heart F, migrates more slowly than $\mathrm{L}$. from human (10) and rat (34) liver. Ising the same technipue with anti-F, antibody both the of and 3 subunits of $\mathrm{B}_{1}$ were detected in extracts of all the fromen tissues from the control (Figs. 1 and 2). In contrast. no immunoreactive protein was detected in positions corresponding $t o$ e either $E_{10}$ or $E_{1}$ is in extracts from the patient's liver or brain. and only barely detectable trace amounts were present in the heart and kidney homogenates. Extracts of cultured skin fibroblasts were analyed in the same way and were found to contain greatly reduced, hut detectable. amounts of $F_{1}$ and $F_{1} ;$ compared with control fibroblasts, whereas the content of $\mathrm{E}$, and $\mathrm{E}$; antigens was normal (results not shown). There was no evidence for aceumulation of aberrant immunoreactive precursor-peptides in any of the pat-

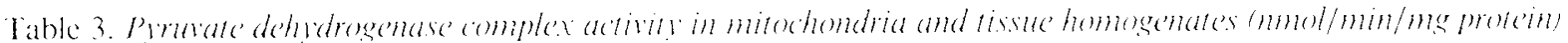

\begin{tabular}{|c|c|c|c|c|c|c|c|}
\hline \multirow[b]{2}{*}{ Tissuc } & \multirow[b]{2}{*}{ Fraction } & \multicolumn{2}{|c|}{ Lintreated } & \multicolumn{2}{|c|}{ Dichloroacetate activated } & \multicolumn{2}{|c|}{ Huoride inaletivated } \\
\hline & & Paticnt & controls* & Patient & controls* & Paticnt & Controls* \\
\hline \multirow[t]{2}{*}{ I.juer } & Mitochondria & 0.25 & $8.1(1.5-2(0)$ & 0.1 & $9.8(4.2-18)$ & 0.1 & $50(0.5-14)$ \\
\hline & Homogenate & 0.20 & $1.6(0.2-4.6)$ & & & & \\
\hline Muscle & $\begin{array}{l}\text { Mitechondria } \\
\text { Homogenate }\end{array}$ & 0.5 & $\begin{array}{l}(07(3+1.27) \\
2.7(0.9-6.7)\end{array}$ & 0.7 & $75(36-127)$ & 0.1 & $53(32-75)$ \\
\hline \multirow[t]{2}{*}{ Kidncy } & Mitochondria & 0.6 & 22 & 0.8 & 24 & 0.5 & 8.6 \\
\hline & Homogenate & (1).2 & $5.3\{2.7-9.5\}$ & & & & \\
\hline \multirow[t]{2}{*}{ Ileart } & Mitochondria & 3.6 & 77 & 3.9 & 62 & 2.0 & 57 \\
\hline & Homogenate & $(0.4$ & $7.2(1.9-16)$ & & & & \\
\hline Brain & Homogenate & (). 1 & $6.4(3.9-9.0)$ & & & & \\
\hline
\end{tabular}

* Control values are means with the range shown in parentheses. Mitochondria from controls were obtained from biopsies (n =:e 11 for liver and 8 for muscte) or from autopsy ( $n=1$ for kidney and heart). Whole tissue samples for homogenates were obtained by biopsy or autopsy ( $n=20$ for liver, 12 for muscle, 4 for kidncy, 6 for heart, and 2 for brain). 
Table 4. Activity of components of pyruvate dehydrogenase complex in skin fibroblasts and mitochondria (nmol/min/mg protein)

\begin{tabular}{clccc}
\hline \multicolumn{1}{c}{ Cell or tissue } & Subject & \multicolumn{1}{c}{$\mathrm{E}_{1}$} & $\mathrm{E}_{2}$ & $\mathrm{E}_{3}^{*}$ \\
\hline Fibroblasts & Patient & 0.04 & 2.9 & 61 \\
& $\begin{array}{l}\text { Controls } \dagger \\
\text { (Range) }\end{array}$ & $0.09 \pm 0.01(7)$ & $2.9 \pm 1.2(10)$ & $39 \pm 17(13)$ \\
& & $(0.06-0.11)$ & $(1.3-5.3)$ & $(19-67)$ \\
Liver mitochondria & Patient & 0.02 & 63 & 824 \\
& Controls $\dagger$ & $0.23(3)$ & $69 \pm 23(5)$ & $510 \pm 118(4)$ \\
& (Range) & $(0.19-0.30)$ & $(30-93)$ & $(351-626)$ \\
Muscle mitochondria & Patient & & 77 & 102 \\
& Controls $\dagger$ & $0.79(3)$ & $94 \pm 44(5)$ & $313(3)$ \\
& (Range) & $(0.34-1.36)$ & $(46-160)$ & $(226-398)$ \\
\hline
\end{tabular}

* The activity of dihydrolipoamide dehydrogenase was measured in the direction of reduction of NAD, except muscle mitochondria were assayed in the direction of NADH oxidation.

$\dagger$ Mean \pm SD for controls, with the number of subjects shown in parentheses. Liver and muscle mitochondria controls from biopsies.

Table 5. Activity of other mitochondrial enzymes related to

\begin{tabular}{|c|c|c|c|}
\hline Cell or tissue & Subject & $\begin{array}{c}\text { Pyruvate } \\
\text { carboxylase }\end{array}$ & $\begin{array}{l}\text { Phosphoenolpyruvate } \\
\text { carboxykinase }\end{array}$ \\
\hline Lymphocytes & $\begin{array}{l}\text { Patient } \\
\text { Controls* } \\
\text { (Range) }\end{array}$ & $\begin{array}{c}0.15 \\
0.08 \pm 0.04 \\
(0.04-0.21)\end{array}$ & $\begin{array}{c}1.76 \\
1.41 \pm 0.52 \\
(0.80-2.81)\end{array}$ \\
\hline Fibroblasts & $\begin{array}{l}\text { Patient } \\
\text { Controls } \dagger \\
\text { (Range) }\end{array}$ & $\begin{array}{c}2.00 \\
1.36 \pm 0.76 \\
(0.45-3.82)\end{array}$ & $\begin{array}{c}6.6 \\
5.0 \pm 3.4 \\
(0.74-13.8)\end{array}$ \\
\hline Liver mitochondria & $\begin{array}{l}\text { Patient } \\
\text { Controlsł } \\
\text { (Range) }\end{array}$ & $\begin{array}{c}287 \\
310 \pm 173 \\
(96-692)\end{array}$ & $\begin{array}{c}436 \\
322 \pm 203 \\
(109-789)\end{array}$ \\
\hline
\end{tabular}

* Control values for lymphocytes from 26 normal adults, mean \pm SD

$\dagger$ Control values from 37 skin fibroblast lines from children, mean \pm SD.

$\ddagger$ Liver mitochondria control values from 10 biopsies, mean \pm SD.

tient's tissues. In a separate experiment, the amounts of both $E_{1}$ peptides were greatly diminished in extracts of liver and kidney mitochondria from the patient relative to a different control. When purified bovine heart $E_{1}$ was mixed with an extract of liver mitochondrial protein from the patient, both $\mathrm{E}_{1} \alpha$ and $\mathrm{E}_{1} \beta$ were present in the expected amounts (results not shown), indicating that failure to detect $E_{1}$ peptides in the patient's tissues was not due to interference with the detection method used.

\section{DISCUSSION}

The findings in this case provide unequivocal evidence for profound systemic deficiency of PDC due to lack of the first component, $E_{1}$. These findings include: 1) persistent lactic acidosis from birth in a neurologically deteriorating infant, with a normal lactate to pyruvate ratio and without other metabolic abnormalities in blood and urine except for increased alanine; 2) inability of isolated mitochondria from liver, skeletal muscle, kidney, or heart to oxidize pyruvate; 3) markedly decreased activity of PDC in isolated lymphocytes, skin fibroblasts, liver and muscle mitochondria, and frozen liver, kidney, heart, and brain; 4) decreased activity of the $E_{1}$ component and normal activity of $E_{2}$ and $E_{3}$ in fibroblasts and liver and muscle mitochondria; and 5) undetectable or greatly diminished amounts of immunoreactive proteins corresponding to the $\alpha$ and $\beta$ subunits of $E_{1}$ with normal content of the $E_{2}$ and $E_{3}$ proteins in liver, brain, kidney, heart, and skin fibroblasts. No other case of PDC deficiency has been so thoroughly characterized.

It is difficult to comprehend how this infant was able to oxidize

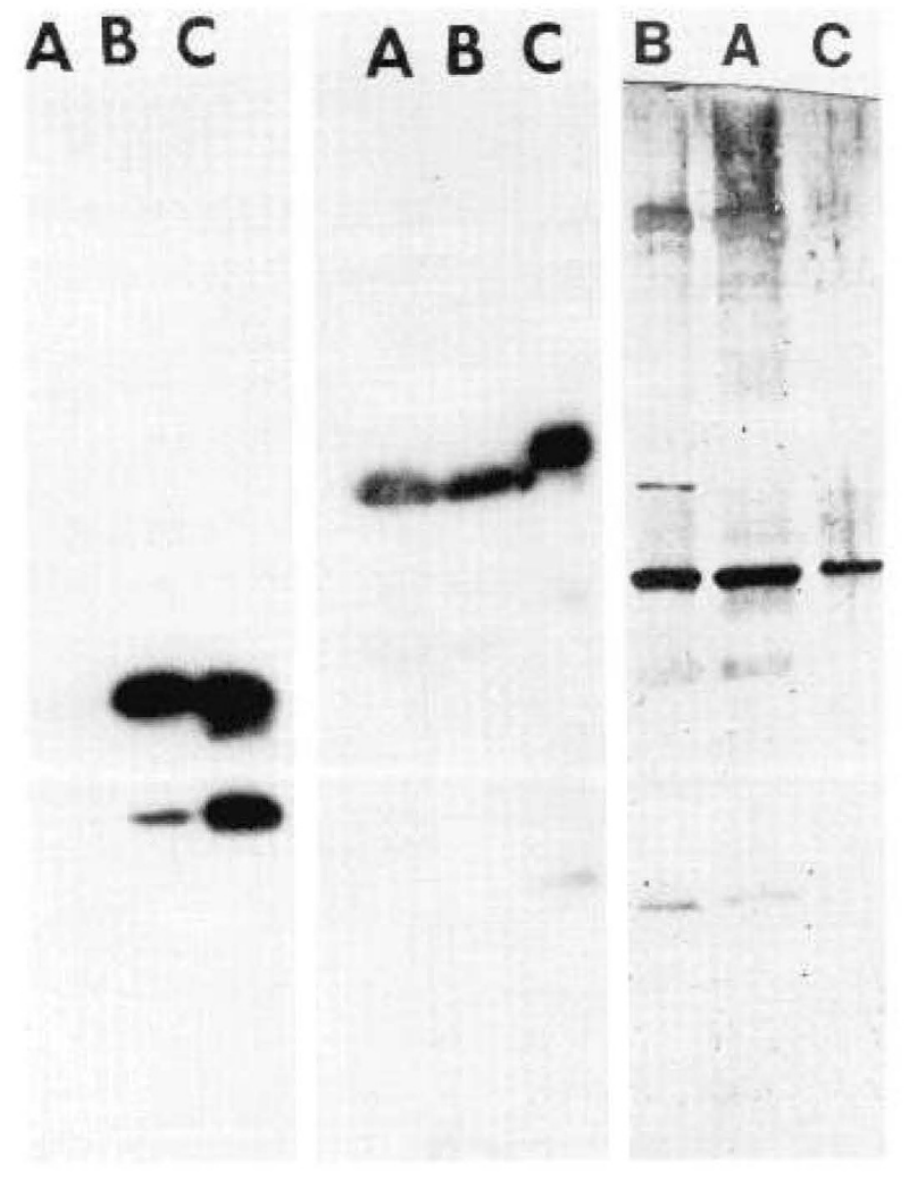

Fig. 1. Immunoblot analysis of PDC components in liver from the patient and a control. Left, $\mathrm{E}_{1}$ immunoblot of liver homogenates. Extracts of homogenized frozen liver were used for analysis (aliquots are expressed in relation to their content of DNA). The membrane was treated with anti- $E_{1}$ serum followed by $\left[{ }^{125} \mathrm{I}\right]$-protein A. I.ane A, patient $(28 \mu \mathrm{g}$ of DNA): lane $B$, control (15 $\mu \mathrm{g}$ DNA); lane $C$, purified bovine kidney $\mathrm{E}_{1}$ (upper band: $\mathrm{E}_{1} \alpha$; lower band: $\mathrm{E}_{1} \beta$ ). Middle, $\mathrm{E}_{2}$ immunoblot of liver homogenates. Extracts of liver homogenates containing similar quantities of DNA were analyzed. The membrane was treated with anti- $E_{2}$ serum followed by [125I]-protein A. Lane A, patient (7.7 $\mu \mathrm{g}$ DNA); lane B, control (7.6 $\mu \mathrm{g} \mathrm{DNA}$ ); lane $C$, purified bovine heart $\mathrm{E}_{2}$. Right, $\mathrm{E}_{3}$ immunoblot of liver mitochondria. Mitochondrial extracts containing equal amounts of protein were analyzed. The membrane was treated with anti- $\mathrm{E}_{3}$ serum followed by goat antirabbit IgG conjugated with horse radish peroxidase. Lane $A$, patient (50 $\mu$ g protein); lane $B$, control (50 $\mu \mathrm{g}$ protein); lane $C$, purified bovine heart $\mathrm{E}_{3}(0.20 \mu \mathrm{g}$ protein). 


\section{A B C DEF G D F GA}

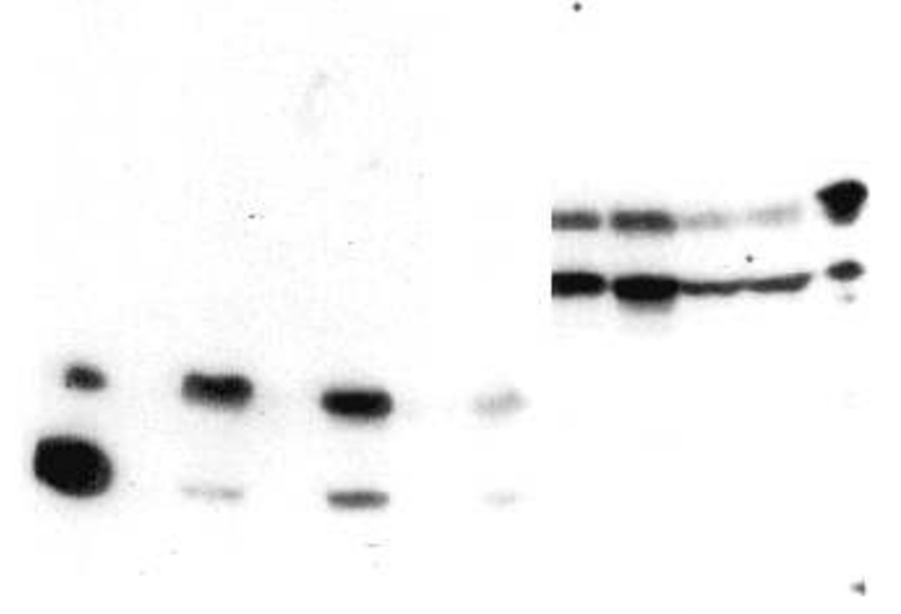

Fig. 2. Immunoblot of $P I X C^{\prime}$ components in kidney, heart, and brain homogenates from the patient and a control. I.eft. F, immunoblot. Fxtracts of homogenates of frozen tissues containing $0.4 \mathrm{mg}$ of protein were analyzed. The membrane was treated with anti-F, serum followed by $\left[{ }^{125}\right]$-protein $\mathrm{A}$. Lpper hand, $\mathrm{E}_{1} \alpha$ : lower band, $\mathrm{E}_{1} \beta$. Righl, simultaneous immunoblot of $E_{2}$ and $E_{3}$. Lixtracts of homogenates containing 0.2 mg of protein were analyed. The membrane was treated simultaneously with anti-lis and anti-l; sera followed by [ $\left.{ }^{125} \mathrm{I}\right]$-protein A. Lpere hand. $\mathrm{E}_{2}$; lower hand. $\mathrm{E}_{3}$. Beth panels, lane $A$, bovine heart PDC: lane $B$,

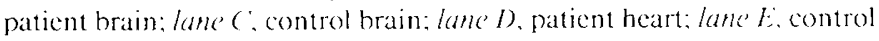
heart; lane $l$, patient kidney; lame' $(j$, control kidney.

pyruvate at all or survive for even as long as he did with so little residual PIX activity. Remarkably. there was no evidence of cardiomyopathy or hepatic or renal dysfunction. It is conceivable that the $E_{1}$ subunits were present in greater amounts in vivo but were uniquely labile and hence disappeared during sample processing, or, alternatively, the $E_{\text {, was }}$ wresent at a higher level earlier in development and gradually disappeared before death. However, there are no data to support these possibilities, and the lack of PDC activity in freshly isolated lymphocytes and the specific failure of otherwise metabolically active intact mitochondria to oxidize pyruvate cannot be explained as postmortem artifacts. Glucose oxidation is largely dependent on flux through PDC. and flux through PIC is regulated in part by the state of phosphorylation of $\mathrm{E}_{1}$ : since inactivation of normal PDC by phosphorylation results in less loss of activity than was observed in this defect (as shown Table 1), it is difficult to imagine that the very small amounts of residual $P I)\left(\right.$ activity or $E_{1}$ found. for example, in this infant's heart and kidney would be sufficient to account for more than minimal energy production from glucose oxidation. One must presume, therefore. that most of the energy required by liver, skeletal muscle. heart. and kidney was derived from oxidation of fatty acids, at least postnatally.

As has been described in other cases of PDC deficiency, brain function and development were severely impaired and pathological abnormalities were confined to the central nervous system. This suggests that dependence on pyruvate oxidation as an energy source is relatively unique to certain areas within the central nervous system, consistent with the well known effects of glucose deprivation on brain functioning. Why the affected areas are particularly vulnerable to lack of PDC is not known. Fetal development was apparently normal, and this is difficult to reconcile with the more general dependence of the fetus on glucose oxidation as an energy source. Conceivably, chronic adaptation of the fetus to nonoxidative glycolysis (which provides less than $10 \%$ as much energy as glucose oxidation) and of the mother to gluconeogenesis from lactate (the Cori cycle) could have provided sufficient energy for the fetus, although there is no evidence that this type of accelerated recycling actually occurs.

The significant neuropathological findings included bilateral necrosis of the putamen. caudate, and spinal cord with demyelination and axonal loss in the optic nerve and spinal cord tracts. These changes are consistent with the necrotizing encephalomyelopathy described by leigh (35). Similar neuropathological findings have been described in several previously reported cases of PDC deficiency $(7,36,37)$, including a recent case which was also shown to lack both subunits of the $E_{1}$ component in skin fibroblasts (10,38). This latter patient lived for 7 yr. had optic atrophy, retinal changes, episodic ataxia, and a central hypoventilation syndrome. The neuropathological findings in the present case and this latter case are similar, with evidence of involvement of the basal ganglia and optic nerves. However, the latter case had more severe involvement of these areas as well as involvement of the cerebellum and brain stem. This degree of variation has been described within the spectrum of the neuropathology associated with Leigh's disease. and in these two biochemically. similar cases could be due to different ages at death and differences in the amount of residual PDC activity. PIC deficiency should be included as one of the possible contributing defects. Earlier reports had suggested an association of I eigh's discase with other defects of pyruvate metabolism, including pyruvate carboxylase deficiency. but careful investigation of a scrics of cases of well-established I eigh's disease failed to provide cridence for pyruvate carboxylase deficiency $(39.40)$.

Skin fibroblasts from this patient did not accurately reflect the severity of PDC deficiency which was evident in all other cells and tissues. Fibroblasts have been used most commonly for detection of PDC deficiency. I ymphocytes in this case reflected the severity of systemic PDC deficiency more accurately and lymphocytes provide a practical alternative to fibroblasts for detection purposes (29). 'Reduced PDC activity has been detected in skin fibroblasts from parents of children with PIXC deficiency, consistent with the obligatory heterorgous state of an autosomal recessively transmitted genetic disorder (15). We were not able to demonstrate significantly reduced PI) ( activity in lymphocytes from the mother. possibly because of the large variation of controls. Further family studies were not possible because the parents were not available and had no other children in common.

The nearly complete absence of the or and $x$ subunits of $I \vdots$ in tissues from this case accounts for the great reduction of $P I)($ activity. since $E_{1}$ is the rate-limiting ensyme in the overall reaction. The activity of the partial reaction catalyed by $I_{1}$ was also very low. Since this activity is normally very low it is of limited significance as a measure of $E_{1}$ function. ()ther investigators have also found rates for $E_{1}$ which are not more than about $10 \%$ of the nonactivated rate. For these reasons, definition of $F_{1}$ deficiency should at least include evidence of normal $E_{\text {a }}$ and $E_{3}$ activity, and is greatly strengthened, as in the present case. by the additional finding of altered immunoreactivity of electrophoretic mobility of one of the $E_{1}$ proteins. However. other $\mathrm{E}_{1}$ mutants may not show any abnormality in this type of immunological analysis.

The marked reduction in amounts of both a and is subunits of $F_{1}$ is intriguing. since it would not be expected that a single mutation would affect two separate proteins. A similar reduction of both subunits was detected in skin fibroblasts from one other case of $E_{1}$ deficiency (10). In another case, the a subunit was found to be missing (11), and in four additional reported cases of apparent $E_{1}$ deficiency both subunits were found to be present 
by immunological analysis $(9,11)$. Some possible explanations for absence of these two gene products are : 1) mutation of a single regulatory genetic locus could prevent expression of two separate genes; and 2) one subunit could be synthesized and the other not and in the absence of the second subunit the first might be rapidly degraded. Recently, distinct cDNAs for $\mathrm{E}_{1} \alpha$ and $\mathrm{E}_{1} \beta$ have been isolated in our laboratory (42). As there is no immunological cross-reactivity between proteins produced from these cDNAs or cross-hybridization of specific oligodeoxynucleotide probes, it is very unlikely that there is a common protein or mature mRNA from which $\mathrm{E}_{1} \alpha$ and $\mathrm{E}_{1} \beta$ are derived. The possibility that a large deletion could result in loss of genetic material from two proximal loci is not consistent with the observation that small amounts of $\mathrm{E}_{1} \alpha$ and $\mathrm{E}_{1} \beta$ were present, especially in cultured skin fibroblasts. There was no evidence for accumulation of a higher molecular weight precursor protein in the extracts of whole tissues. ${ }^{2}$ Resolution of the mechanism of this combined defect awaits further application of techniques for examining the respective genes and their products.

Acknowledgments. The authors are grateful to Susan Hutson, Russell Scaduto, Jane Kirschman, and Julia Turkaly for technical assistance in the preparation and polarographic assays of mitochondria, to Dr. Nancy Kenaway for providing samples of kidney and heart mitochondria from a control subject, to Dr. Lester Reed for providing purified PDC components, to Cindy Raefsky and Donna Carothers for preparation of anti- $E_{2}$ and anti- $E_{3}$ sera, respectively, and to Drs. William Dahms, Ruth Owens, and Arthur Zinn for comments concerning preparation of the manuscript.

\section{REFERENCES}

1. Blass JP 1983 Inborn errors of pyruvate metabolism. In: Stanbury JB, Wyngaarden JB. Fredrickson DS. Goldstein JL. Brown MS (eds) The Inherited Basis of Metabolic Disease. 5th ed. McGraw-Hill New York. pp 193-203

2. Robinson BH, Taylor J, Sherwood WG 1980 The genetic heterogeneity of lactic acidosis: occurrence of recognizable inborn errors of metabolism in a pediatric population with lactic acidosis. Pediatr Res 14:956-962

3. Blass JP. Avignan J. Uhlendorf BW 1970 A defect in pyruvate decarboxylase in a child with an intermittent movement disorder. J Clin Invest 49:423432

4. Farrell DF, Clark AF, Scott CR, Wennberg RP 1975 Absence of pyruvate decarboxylase activity in man: $A$ cause of congenital lactic acidosis. Science 187:1082-1084

5. Stromme JH, Borud O, Moe PJ 1976 Fatal lactic acidosis in a newborn attributable to a congenital defect of pyruvate dchydrogenase. Pediatr Res 10:60-66

6. Kuroda Y, Kline JJ, Sweetman L, Nyhan WL, Groshong TD 1979 ^bnormal pyruvate and $\alpha$-ketoglutarate dehydrogenase complexes in a patient with lactic acidemia. Pediatr Res 13:928-93

7. Toshima K. Kuroda Y, Hashimoto T, Ito M, Watanabe T, Miyao M, Ii K 1982 Enzymological studies and therapy of Leigh's disease associated with pyruvate decarboxylase deficiency. Pediatr Res 16:430-435

8. Robinson BH 1983 Inborn errors of pyruvate metabolism. Biochem Soc Trans 11:623-626

9. McKay N, Petrova-Benedict R, Thoene J, Bergen B, Wilson W, Robinson B 1986 Lacticacidemia due to pyruvate dehydrogenase deficiency, with evidence of protein polymorphism in the $\alpha$-subunit of the enzyme. Eur J Pediatr $144: 445-450$

10. Ho L, Hu C-WC, Packman S, Patel MS 1986 Deficiency of the pyruvate dehydrogenase component in pyruvate dehydrogenase complex-deficient human fibroblasts: immunological identification. J Clin Invest 78:844-847

11. Wicking CA. Scholem RD, Hunt SM, Brown GK 1986 Immunochemical analysis of normal and mutant forms of human pyruvate dehydrogenase. Biochem J 239:89-96

12. Reed LJ, Willms CR 1966 Purification and resolution of the pyruvate dehy-

${ }^{2}$ In vitro translation experiments have indicated that both $E_{1} \alpha$ and $E_{1} \beta$ are initially synthesized as precursor peptides whose molecular weights are about $10 \%$ larger, as determined by immunoprecipitation and SDS-polyacrylamide gel electrophoresis (Raefsky C, Patel M, unpublished data). drogenase complex (E. coli). Methods Enzymol 9:247-265

13. Matuda S, Kitano A, Sakaguchi Y. Yoshino M. Saheki T 1984 Pyruvate dehydrogenase subcomplex with lipoamide dehydrogenase deficiency in a patient with lactic acidosis and branched chain ketonuria. Clin Chim Acta 140:59-64

14. Fotino M, Merson EJ, Allen FH 1971 Micromethod for rapid separation of lymphocytes from peripheral blood. Ann Clin Lab Sci 1:131-133

15. Sheu K-FR, Hu C-WC, Utter MF 1981 Pyruvate dehydrogenase activity in normal and deficient fibroblasts. J Clin Invest 67:1463-1471

16. Chuang Dr, Niu W-L. Cox R 1984 Activities of branched-chain 2-oxo acid dehydrogenase and its components in skin fibroblasts from normal and classical maple syrup urine disease subjects. Biochem J 200:59-67

17. Atkin BM, Utter MF, Weinburg MB 1979 Pyruvate carboxylase and phosphoenolpyruvate carboxykinase activity in leukocytes and fibroblasts from a patient with pyruvate carboxylase deficiency. Pediatr Res 13:38-43

18. Lowry OH, Rosebrough NJ, Farr AL, Randall RJ 1951 Protein measurement with Folin phenol reagent. J Biol Chem 193:265-275

19. Schneider WC, Hogeboom GH 1950 Intracellular distribution of enzymes. V. Further studies on the distribution of cytochrome $\mathrm{c}$ in rat liver homogenates. J Biol Chem 183:123-128

20. Hoppel CL, DiMarco JP, Tandier B 1979 Riboflavin and rat hepatic cell structure and function: mitochondrial oxidative metabolism in deficiency states. J Biol Chem 254:4164-4170

21. Tomec RJ, Hoppel CL 1975 Carnitine palmitoyltransferase in bovine heart mitochondria. Arch Biochem Biophys 170:716-723

22. Chappell JB, Perry SV 1954 Biochemical and osmotic properties of skeletal muscle mitochondria. Nature 173:1094-1095

23. Zinn AB, Kerr DS, Hoppel CL 1986 Fumarase deficiency: a new cause of mitochondrial encephalomyopathy. N Engl J Med 315:469-475

24. Estabrook RW 1967 Mitochondrial respiratory control and polarographic measurement of ADP/O ratios. Methods Enzymol 10:4I-47

25. Laemmli UK 1970 Cleavage of structural proteins during assembly of the head of bacteriophage T4. Nature 227:680-685

26. Vaitukaitis JL 1981 Production of anti-sera with small doses of immunogen: multiple intradermal injections. Methods Enzymol 73:46-52

27. Hurn BAL. Chantler SM 1980 Production of reagent antibodies. Methods Enzymol 70:104-142

28. Vytasek R 1982 A sensitive fluorometric assay for the determination of DNA Anal Biochem 120:243-248

29. Kerr DS. Levy M 1985 Pyruvate dehydrogenase deficiency expressed in lymphocytes. Pediatr Res 19:314(abstr)

30. Hansford RG 1976 Properties of mitochondria from animal and plant tissues. In: Altman PL, DD Katz (eds) Cell Biology, Biological Handbooks I. Fed Am Soc Exp Biol, Bethesda, MD, pp [45-148

31. LaNoue KF, Walaitys EI, Williamson JR 1973 Regulation of glutamate metabolism and interactions with the citric acid cycle in rat heart mitochondria. J Biol Chem 248:7171-7183

32. Moreadith RW, Batshaw ML, Ohnishi T, Kerr DS, Knox B, Jackson D Hruban R, Olson J, Reynafarje B, Lehninger A 1984 Deficiency of the ironsulfur clusters of mitochondrial NADH-ubiquinone oxidoreductase (complex I) in an infant with lactic acidosis. J Clin Invest 74:685-697

33. Whitehouse S, Cooper RH, Randle PJ 1974 Mechanism of activation of pyruvate dehydrogenase by dichloroacetate and other halogenated hydrocarbons. Biochem J 141:761-764

34. DeMarcucci O, Lindsay JG 1985 Component X. An immunologically distinct polypeptide associated with mammalian pyruvate dehydrogenase multienzyme complex. Eur J Biochem 149:641-648

35. Dayan AD, Ockenden BG, Crome L 1970 Necrotizing encephalomyelopathy of Leigh. Neuropathological findings in 8 cases. Arch Dis Child 45:39-48

36. DeVivo DC, Haymond MW, Obert KA, Nelson JS, Pagliara AS 1978 Defective activation of the pyruvate dehydrogenase complex deficiency in subacute necrotizing encephalomyelopathy (Leigh disease). Ann Neurol 6:483-494

37. Ohtake M, Takada G, Miyabayashi S, Arai N, Tada K, Morinaga S 1982 Pyruvate decarboxylase deficiency in a patient with Leigh's encephalomyelopathy. Tohoku J Exp Med 137:379-386

38. Kretzschmar HA, DeArmond SJ, Koch TK, Patel MS, Newth CJL Schmid KA, Packman S 1986 Pyruvate dehydrogenase complex deficiency as the etiology of Leigh's disease. Pediatrics 79:370-373

39. Atkin BM, Buist NR, Utter MF, Leiter AB, Banker BQ 1979 Pyruvate carboxylase deficiency and lactic acidosis in a retarded child without Leigh's disease. Pediatr Res 13:109-116

40. Murphy JV, Isohashi F, Weinberg MB, Utter MF 1981 Pyruvate carboxylase deficiency: An alleged biochemical cause of Leigh's disease. Pediatrics 68:401-404

41. Kerr DS, Ho L, Berry SA, Patel M 1987 A deficiency of both subunits of the pyruvate dehydrogenase complex that is not expressed in fibroblasts. Fed Proc 46:2163(abstr)

42. Ho L, Javed AA, Pepin RA, Raefsky C, Mole JE, Jesse BW, Kerr DS, Patel MS 1987 Identification of cDNA clones for the $\alpha$ and $\beta$ subunits of the pyruvate dehydrogenase complex. Fed Proc 46:2165(abstr) 